\title{
Cooperating with Moscow, Stealing in California: Poland's Legal and Illicit Acquisition of Microelectronics Knowhow from 1960 to 1990
}

\author{
Mirosław Sikora $($ 四) \\ Jagiellonian University, 31-007 Kraków, Poland \\ Institute of National Remembrance, Regional Branch, 40-145 Katowice, Poland \\ miroslaw.sikora@yandex.com
}

\begin{abstract}
Electrical calculating machines were designed and manufactured in Poland in small quantities during the 1950s. However, it soon become clear to the government that an autonomous advance in that cutting-edge discipline was simply impossible. Therefore, throughout the 1960s, Polish authorities established various channels of obtaining access to software solutions, transistors and especially integrated circuits that seem to become standard for years to come. The way of adopting IT by communist Poland did not differ much from how it was done in USSR - according to the model described by Mastanduno. It was a smart combination of legal measures like the use of trade agreements, official scientific-technical cooperation and illicit operations run with help of intelligence assets like bribing or blackmailing officials and employees, establishing fake intermediating companies for purchasing embargoed dual-use items. Therefore, medium and large-scale-integration-technology as well as specific types of computers like mainframes, minicomputers and later PCs along with peripheral devices came to the Polish People's Republic through many routes. Moreover, Polish intelligence intensified its cooperation and information sharing with Soviet foreign intelligence service - like its counterparts in GDR, Hungary, etc. As a result, not only ties to the Western world were organized over and under the table, but also relationships with allies in Comecon were arranged in two dimensions. The case of Poland gives an excellent example of how schizophrenic the computer market under Comecon during the 1970s and 1980s was. This paper refers to the research project conducted by the author in the Institute of National Remembrance since 2011 and at the Jagiellonian University since 2018, entitled: "Scientific-technical intelligence of PPR: functions, organization, efficiency." In this contribution the author presents the outcomes of the analysis of the Polish archival sources completing them by foreign archives and secondary sources.
\end{abstract}

Keywords: CoCom $\bullet$ Cold War $\bullet$ COMECON (CMEA) • Industrial Espionage • Poland $\bullet$ Technology Transfer. 


\section{Introduction}

In Poland, electrical calculating machines such as XYZ, EMAL and UMC were designed and constructed in small quantities during the 1950s under the supervision of mathematicians and engineers. Among them were professor Leon Łukaszewicz from the Polish Academy of Sciences, Romuald Marczyński from the Institute of Nuclear Research and Antoni Kiliński from the Warsaw University of Technology. In 1959, the first Polish computer factory Elwro in Wroclaw was established. After a couple of years of experiments with vacuum tube technology, it launched the production of famous "Odra" computers based on the transistor logic [1-2]. Because of Cold War tensions, Polish scientists and managers did not have any significant access to western knowledge until the late 1950s. When the U.S. government started its so-called differential policy against Poland, they assumed that the thaw under Władysław Gomułka would stepwise bring the Polish state away from the communist camp [3].

Obtaining at least limited access to scientific-technical exchange programs with the USA and other Western countries through foreign scholarship programs like the British Council, DAAD, Humboldt Stiftung, Fort Foundation, Rockefeller Foundation and UN-endorsed international projects, the Polish government started to collect data on the current global development of computer science and engineering [4].

According to detailed analysis delivered by experts working for Polish ministries and think-tank institutes in the 1950s and 1960s, an autonomous advance in that cutting-edge discipline was simply impossible except for superpowers like the U.S. or the Soviet Union [5]. Therefore, throughout the 1960s, Polish authorities came up with various channels of obtaining access to computer technology solutions, especially transistors and integrated circuits that seemed to become standard for years to come. Moreover, embargo restrictions imposed by countries adhering to standards set by the Coordinating Committee for the Multilateral Export Controls (CoCom), on dual-use items, ${ }^{1}$ including advanced microelectronics equipment and components that had both civilian and military purposes, did very soon make clear to Polish authorities that any significant progress in computer $R \& D$ without taking advantage of illicit measures was impossible. Therefore, already in the turn of 1950s and in the 1960s, the Polish intelligence service was charged with tasks of penetrating West European and American companies as well as smuggling embargoed solutions. The idea of intelligence involvement came from Moscow, where the foreign intelligence service had been used as a tool in the scientific-technical purposes of computer science since the early 1940s [6].

The author's point is to sketch four trajectories (routes) of computer science and equipment transfer that determined the Polish computer market during the Cold War next to the contribution of Polish scientists, engineers and managers. In the future, the author would like to try to determine which of those paths was most efficient, taking into consideration all constraints of that time like the Cold War, planned economy, Polish dependency on USSR, overall technological lag against the West, etc.

\footnotetext{
${ }^{1}$ See Leslie, "From CoCom to Dot-Com," this volume.
} 


\section{$2 \quad$ Methodology}

This paper refers to the research project conducted by the author at the Institute of National Remembrance since 2011. After 2018, it has been supported by the National Science Center (NCN) and endorsed by Jagiellonian University, entitled: "Scientifictechnical intelligence of PPR: functions, organization, and efficiency." The author analyses Polish, German, Russian and US archival resources and consults Polish specialists on IT who were insiders of PPR's computer industry during the 1970s and 1980s.

The core set of sources regarding the legal transfer of computer know-how and equipment to the Polish People's Republic (PPR) during the Cold War provides the heritage of the Polish Ministry of Machine Industry, since 1981 including metallurgy, responsible for the electronics branch of the industry [7-8]. Furthermore, the records of the Committee for the Science and Technology [9] and its continuation as the Office for the Scientific-Technical Progress and Implementation [10], available in the Polish Central Archives for the Modern Records (Archiwum Akt Nowych - AAN) in Warsaw, provide insight into the Polish-Soviet high-tech exchange.

The mutual cooperation between Poland, Soviet Union and other states from the Committee for the Mutual Economic Assistance, also known as Comecon or CMEA can be reconstructed by the analysis of extensive reports produced annually by the various Comecon bodies [11]. Probably the best insight into the cooperation in the area of computers deliver documents of the Permanent Committee for the Radiotechnical and Electronics Industry along with its many sub-committees, occupied with such narrow areas like only integrated circuits [12]. Finally, both the records of Soviet and Polish Permanent Commissions to the Comecon seem to be worth an investigation, although the latter are not yet available for the researchers. Comecon documents are stored and accessible in the Russian State Archive of the Economy (Rossiyskiy Gosudarstvennyy Arkhiv Ekonomiki, or RGAE).

These sources can be effectively extended by inclusion of domestic documents produced by other Comecon members, though the linguistic obstacle seems to be crucial here. The author was able to investigate only the files produced by GDR, both those documenting official and legal aspects of mutual contacts between Poland and East-Germany in the area of computers [13] and those produced by intelligence services involved in clandestine intelligence share [14].

The hidden, clandestine, illicit dimension of the Polish computer industry and its research and development (R\&D) efforts reflects itself in the files, records and cables of Polish foreign intelligence service, in particular, in its branch assigned to the gathering of scientific-technical data in almost every discipline of science. Records available nowadays in the Archive of the Institute of National Remembrance (IPN) in Warsaw cover the period of time from early 1950s till the 1990s. Documents are, however, unequally distributed over this time span, in the way that their number is increasing along with the time they are referring to. Hence, insight into the 1980s and 1970s is much better than into the 1960s and 1950s. Such a trend results partly from the procedure of destruction of old documents considered as useless. That was taking place on a regular basis every five or ten years in the intelligence archive. 
Unfortunately, such an asymmetry is found just in opposite to the common archival resources in the West, which complicates any attempts of comparative studies. For instance, one can learn a lot from the files stored in the National Archives and Records Administration/NARA in College Park, Maryland of such U.S. agencies as the International Trade Administration (ITA) linked to the Department of Trade. Among them especially from the Bureau of Foreign Commerce - Office of Economic Affairs and the Bureau of East-West Trade - Office of Export Control, as well as from records of Department of State. Nonetheless, the bulk of declassified files originate from the 1950s, 1960s, and to limited extent from the 1970s, while files from the 1980s cannot be accessed by historians as they are still classified.

\section{Thesis}

According to the author's hypothesis, the Polish state gained remarkable benefits from the outcomes of the scientific-technical intelligence (STI) operations and its cooperation with fraternal services in Comecon. Those "incomes" however - and this is the second part of the hypothesis - did not compensate shortages and failures of the Polish R\&D that was forced to work within the constraints of the inefficient planned economy.

Despite of the general incapability to overcome the technological gap in the race with the West, scientific-technical intelligence was able to produce a significant impact on science and R\&D in selected areas of microelectronics and IT. Due to the calculations of the powerful Polish intelligence service's chief Mirosław Milewski delivered to the government in the beginning of the 1970s, Polish scientific-technical intelligence had been helping to economize on an average of US\$50 million annually and had been about to increase this capacity up to $\$ 100$ million in 1975 [15]. Furthermore, as we can learn from a report produced in 1989, scientific-technical intelligence services had tried to capture with its clandestine methods solutions for the economy worth some US\$300 to 500 million annually in the late 1980s [16]. Approximately half of those savings were in the domain of computing and automatic control systems.

In the course of the project, the author intends also to verify his hypothesis about the quantitative share and significance of both civil and military tasks in the agenda of scientific-technical intelligence related to computers during the examined period of time. According to this hypothesis, Polish scientific-technical intelligence contributed most of all to the civil economy and not to the military complex, as it was the case of the KGB and USSR. A contemporary notion about the par excellence military goals of the Polish scientific-technical intelligence is widespread among Polish historians. It derives from the influential works of the former collaborator of the scientifictechnical intelligence in the U.S., the famous spy Marian Zacharski and his informant William Bell in Hughes Aircraft Corporation, California [17].

This study is not about how the Polish computer industry developed but where the inspirations, incentives and know-how embedded in components came from. Moreover, the project and this article skips the aspect of the massive legal and illegal trans- 
fer of (8-bit) personal computers allowed by CoCom to sell to Comecon during the second half of the 1980s. There are comprehensive studies published in this regard $[18,19]$.

\section{$4 \quad$ Poland's Starting Position in the Computer Market}

In the post-war period, electronic calculating machines were among the superinnovative fields of science and industry. Poland whereas - heavily destroyed during WWII - had to concentrate on the reconstruction and possible expansion of basic branches, such as heavy and chemical industries. Apart from computers, when it came to modern technologies, telecommunication and radio communication were of fundamental importance. One of the most crucial requirements of modernization was the construction of the land communication infrastructure and telephone networks. When considering Poland's position in terms of computerization, it is worth considering the backwardness of its telephone infrastructure in relation to the OECD zone, but also in relation to some Comecon countries. In 1961, the number of telephones per 100 inhabitants in Poland was just a bit over 3, while in Sweden it was 33, in the United Kingdom it was 16 and in East Germany it was 8 [20].

Poland's backwardness in telecommunication was only a part of the great challenge faced by the entire communist block and in particularly USSR, for instance while lunching works on All-State Automated System - so-called OGAS. ${ }^{2}$ Regarding the improvement of data transfer and networking both in the societal and economic aspects [21], another challenge for the Polish industry was to supply domestic customers with a sufficient number of radio and land communication equipment operating in the ultra-short wave band, very high frequency. As indicated in an analysis of March 1966, there were about 3,000 mobile radio devices in operation in Poland, while demand in the years 1966-1970 amounted to about 40,000. Just for comparison, in the U.S. in 1965 there were 22 million such devices in operation. In West Germany there were 18,000 of them in 1960, aiming for 200,000 in 1970 [22].

It is difficult to assess today to what extent the authorities of the People's Republic of Poland in the second half of the 1940s were aware of the importance of computers for the country's economy. However, it is not impossible to draw conclusions on this issue. The analysis of the content of popular scientific magazines addressed especially to students, teachers, and engineers gives an idea of which disciplines of science and engineering and the branches of industry have become the subject of interest of journalists. Especially insightful are those entitled Young Technician, Horizons of Technique and Horizons of Technique for the Youth. Indeed, the 1950s brought a gradual increase in the number of articles on the logic of computers and cybernetics and their design like vacuum tubes and then transistors. The applications of computers in science, medicine, industry, transport and communication, robots including those equipped with artificial intelligence and automation systems were seen more widely [23-25].

\footnotetext{
${ }^{2}$ See Kitov, "On the History of Gosplan,” this volume.
} 
Polish specialists were well aware of the economic effects of transistorization in the 1960s. That means the transition from vacuum tube systems to transistors/semiconductors in the manufacture of electronic equipment like radio and television sets, teletransmission equipment. In addition, while improving technical performance and reliability, miniaturization had also dramatically reduced production and operating costs. Above all, it contributed to reducing electricity usage by several times. In the first half of the 1960s government established specialized authorities (as plenipotentiary for electronic computing technique) to oversee development of young Polish computer industry and prepare long-term plans. In December 1965, the Minister of Heavy Industry, which was then in charge of electronics, instructed the Electronic and Telecommunications Industries Association (UNITRA) to set up a working group to develop a comprehensive transistorization program for electronic equipment in the years 1966-1970 within the entire national economy. Later on, UNITRA was divided into UNITRA and MERA companies. MERA was responsible for computers, automatic control and measurement equipment while UNITRA focused on RTV equipment and electronic components.

An extensive analysis carried out in 1966 by specialists of the electronics and telecommunications team of the Committee of Science and Technology (Komitet Nauki $i$ Techniki, or KNiT) concluded that the level of production of semiconductors and electronic components in the PPR was five years behind in comparison to the leading countries. More worrying, however, was the fact that this distance was supposed to increase over the years to come [26].

The state of affairs outlined in the justification for the above resolution was at least disturbing. As estimated in 1965, a total number of about 9,400 computers were in operation in Europe, not including the Comecon countries. Meanwhile, there were barely 76 machines in operation in Poland, roughly the same number as in Ireland at that time. However, there were already 359 in Belgium and 1,610 in France; the highest number of calculating machines, 2,280, was recorded in West Germany [27].

Regarding the development of utilities and programming, Poland had to overcome various paradigms concerning the overall attitude to computers that ruled in USSR. There, computer usage focused on scientific research and military applications, instead of introducing computers into production facilities and in daily life. It is too early to apply Benjamin Peters's concept about the bureaucratic obstacles that impeded the development of computer networks in USSR to the Polish case [21]. The same holds true for Slava Gerovitch's claim of militarization and secretiveness in the Soviet computer program as a major mistake of the Soviet leadership [6]. The reception of cybernetics among Polish mathematicians and engineers in the post war decades never attracted larger attention of historians of technology and therefore still requires basic research.

The tasks set by the government for the Institute of Mathematical Machines in Warsaw and its branches in Krakow and Wroclaw in the mid-60s were quite ambitious. It was intended to design real-time management systems for enterprises and, in addition, to develop calculation methods for partial differential equations in areas such as physics, thermodynamics, flexibility theory, hydrodynamics and aerodynamics, as well as geophysics. The researchers were also asked to study topics such as 
computer behaviors in development of human psychological and physiological capabilities, programmed teaching, synthesis and analysis of sound in human-machine communication, and translation of foreign languages. Another intriguing problem was the modeling of natural, i.e., biological and atmospheric, and economic processes, i.e., production, investment and consumption plans [28].

At the end of the 1960s, there were also many evidences indicating that Polish authorities were eager to develop computer technology and were ready to look for solutions wherever it would be possible.

\section{First Path: Learning and Buying from the West: 1950s-1970s}

Since the mid 1950s, the Soviet Union and its satellites wanted to join global markets and were successful in many respects, for example in the export of natural resources and low advanced technologically goods [29]. They failed, however, to overcome the embargo umbrella set up by U.S. administration at the end of 1940s in order to contain Soviet progress in particular concerning atomic energy, the aerospace industry, and calculating machines along with automatic control systems [30].

During the first half of the 1950s, the U.S. and its allies formed CoCom, which launched the first series of restrictions on trade with USSR and its satellites. Over the next decades, other regulations followed limiting dissemination of strategic components, cutting-edge devices and know-how to the communist regimes, including China. However, in the late 1950s if not earlier, military considerations gradually gave way to economic calculations among the CoCom members. Especially, West European governments started to perceive Comecon countries as a promising market for certain - more or less advanced - commodities and technologies, also those of dualuse nature.

The so-called Polish differential in U.S. policy in the area of microelectronics had been launched gradually over the years 1956-1958 along with relaxation of embargo measures toward PPR and increasing willingness of the State Department to grant Poland with "exceptions" for dual-use items. This positive attitude ended abruptly in 1979 with the Export Administration Act, which embodied the end of détente with regard to scientific-technical cross-curtain cooperation.

According to the differential concept, certain solutions should have been shared with Poland as a reward for keeping its distance from the USSR. That approach did not prevent U.S. authorities from scrutinizing Polish requests for embargo "exceptions." The possible military use as well as leakage to USSR was thoroughly examined while checking Polish plants, R\&D facilities and universities, submitting for licenses or commodities, especially regarding oscilloscopes and other testing and measurement equipment for the emerging Polish computer industry [31-33]. Sharing technology with Poland, though risky, was also regarded in Washington as a "gateway" leading into the Warsaw Pact; it enabled U.S. authorities to identify technical and further economic needs of PPR and Comecon as a whole.

As détente became a fact in the first half of the 1960s, frictions started to emerge not only in the forum of CoCom but also within individual countries. The U.S. State 
Department's or International Trade Administration's officials were often discussing whether it made sense to keep outdated solutions away from commerce with Comecon. In addition, British entrepreneurs representing the branch of computing and communication expressed their exasperation after having experienced that electronic items still "controlled" in their countries became meanwhile "decontrolled" in France and sold to Poland [34-35]. With growing concern and jealousy, U.S. companies were observing the West German Grundig's efforts to build up bridgeheads behind the Iron Curtain [36]. During the 1960s, the Polish state annually spent US\$1-1.5 million to purchase electronics components for the Polish computer industry abroad and this funding seemed to grow rapidly [37].

It was in this context at the end of 1965, that the Committee for Foreign Trade (KWGzZ) ordered the creation of posts for employees to foster economic and scientific-technical cooperation at Polish diplomatic missions abroad. The tasks assigned to the newly appointed employees included informing KWGzZ:

about the development trends and achievements of the economy, science and technology of the country of destination, about economic and scientific-technical plans and the way they were implemented, about the economic situation, organizational changes, etc., about economic and scientific-technical cooperation.

Subsequently, these experts were obliged to report to the KWGzZ on specific topics on which Poland could engage in cooperation. The day-to-day duties included reviewing professional periodicals, searching for symposia and congresses, fairs and exhibitions worth visiting by the Polish delegation, as well as supervising the course of internships and the stay of Polish scholarship holders, and exploring the possibility of obtaining scholarships and internships in the country's scientific and industrial centers of interest to the PPR, and finally coordinating the exchange of scientific and technical documentation between the countries [38]. Noteworthy is the list of basic areas of interest for 1967, annexed to the draft guidelines for employees for scientifictechnical and economic contacts abroad. It covers 38 items which should be considered key from the point of view of the Polish economy at that time. In total, two major themes can be distinguished: the largest ones were electronics and automation, including production processes in almost every industry branch like energy, steel, chemical and food industries - a total of 10 topics. Furthermore, the chemical and biotechnological industry stood out, a total of 10 topics as well [39].

Taking advantage of scholarship programs, analysis of western press, and journals, as well as economic contacts of Polish embassies in the western countries, Polish think tanks were able to provide the government an extensive overview of trends in the U.S. and worldwide computer market. For instance, Polish engineer and famous computer constructor Jacek Karpiński visited MIT and Harvard University in the early 1960s [40]. Among the most influential computer experts in Poland was Adam Empacher, who worked for the Polish Center for Scientific-Technical and Economic Information (CINTE) in Warsaw. His early works from 1960 and 1965 included a profound analysis of American computer manufacturers and their products. It is, by the way, hard to believe that those works relied only on an analysis of open sources. Intelligence's involvement in providing some information for CINTE is highly likely [41]. 
Next to the purchase of equipment, Polish officials were inspired by numerous solutions and applications of computers developed in the West. A bold and innovative decision of the Polish government was the establishment of regional electronic computing plants (ZETO), which were to be equipped with computers designed for data processing for the needs of local institutions and state enterprises. The idea referred to the business developed in U.S. already in the 1950s - namely, leasing mainframes to companies or institutions that needed to process large amounts of data. The aim of Polish managers was to save up to 30 percent of the current expenditure on salaries, to reduce the consumption of raw materials, and to speed up the turnover cycle of funds in enterprises using such services [42].

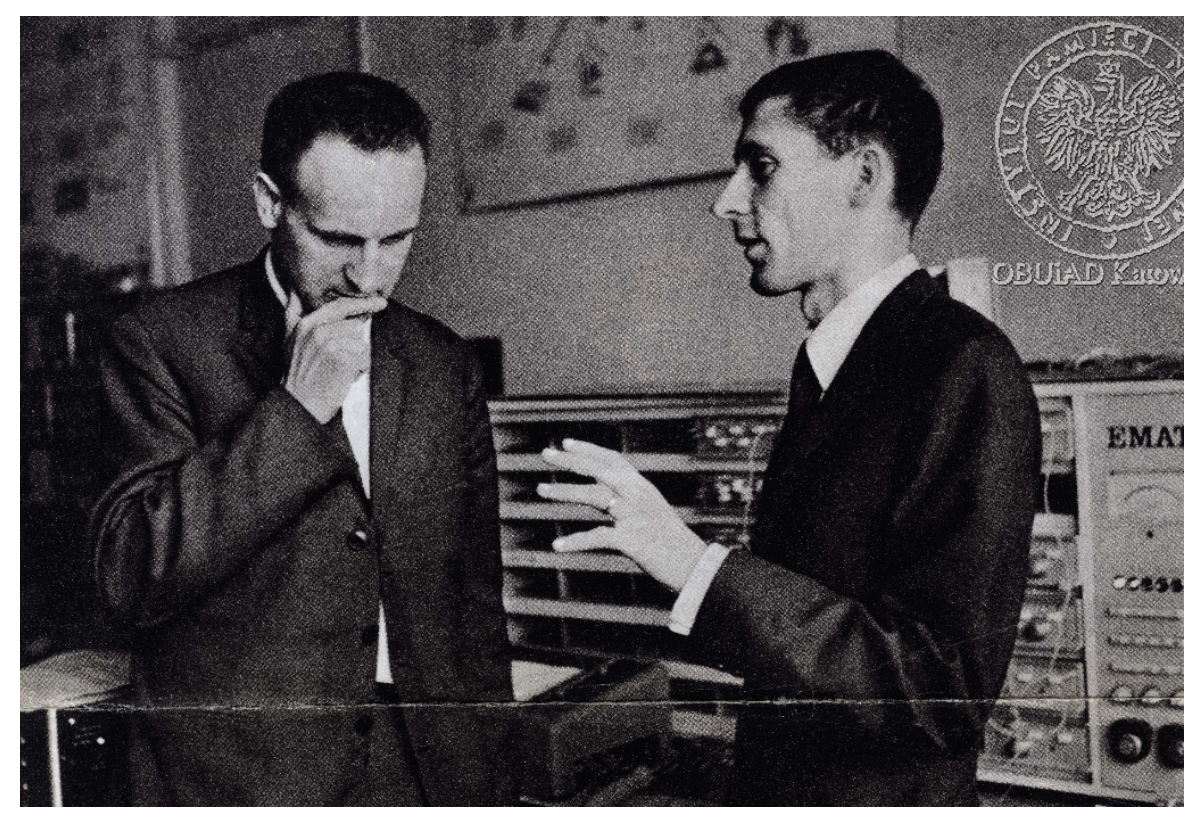

Fig. 1. Polish-French cooperation in the area of automatic control. Prof. Stefan Węgrzyn (who eventually refused to cooperate with Polish intelligence) and Dr. Pierre Vidal in the early 1960s. Source: AIPN Katowice.

The successful introduction of various "Odra" series computers and measurement equipment into mass productions meant tens of computers annually but not hundreds. In the first half of the 1960s, Elwro became a flagship of the Polish computer industry. It was the only company permitted to run trade relationships with western countries by its own involving foreign currencies payments. In the second half of the 1960s, Poland purchased, implemented and even re-exported hardware like 1900 Elliott computers and software like the Operating System George 3 from the British company ICT (later ICL). Later on, Polish officials developed promising contacts with the French company Thomson. The contract with ICL was signed in 1967. It included know-how transfer to the Elwro factory that helped Polish engineers to construct Odra 1304 computers with knowledge of the Elliot ones. The British company 
did not share technical documents of the computer's manufacturing; nevertheless, technical documents of the Elliott 1904 logic as well as the software user manual passed to Elwro along with memory storage containing operational programs were enough to re-invent ("reverse engineer") and even improve the machine. Engineers translated George 3 into Polish and the resulting Odra turned out to be first computer produced worldwide to be fully compatible with another computer produced by a different company. The Odra 1304 was also a huge jump ahead regarding computer application. It was the first computer in Poland to be extensively used for data processing in various branches of economy, i.e., in factories, transportation and offices and not only in scientific calculations [43].

There were not so many similar achievements resulting from legal know-how transfer with the West. In the late 1960s, Poland signed a contract with French Thomson, obtaining access to the advanced transistor technology. Another example refers to Japan, which was part of CoCom. At the beginning of the 1970s, America Fairchild had been refused by the U.S. government to sell integrated circuits of very high scale of integration to Poland. Therefore, the Polish government immediately addressed the Japanese government with a similar request. This annoyed U.S. diplomats, but it was a quite natural step looking from Warsaw's point of view [44]. Contracts were signed up with companies like Busicom and Ricoh later on. Soon, thousands of calculators of very large-scale integration started to leave assembly lines of Elwro [43].

\section{Second Path: Learning from USSR and Cooperation in Comecon: 1960s to 1970s}

Up to the late 1950s, there was almost no activity in Warsaw and Moscow regarding the interchange of experiences and knowledge on computers [45].

USSR assistance to the computer industry turned out to be necessary only starting from the moment of transition from the first to the second generation of computers, i.e., transistors, in the late 1950s. Everything seems to indicate that the opening of the Elwro factory was the domestic work of the government of the People's Republic of Poland and Polish engineers. However, with the transition to semiconductor technology, consultations with the Russians have proved necessary. In the years 1960-1964 a number of contracts for the supply of semiconductor products and semiconductor technologies from the USSR to the PPR were signed up on behalf of the PPR by the enterprise PHZ Polimex and on behalf of the USSR by Tiaazhpromexport. In addition to selling materials, the USSR offered advice at the preparatory stage of assembly lines for manufacturing germanium and silicon transistors by Poland [46-47]. It was the TEWA Semiconductor Factory in Warsaw, the second in importance in Poland after the Elwro plant, that was entrusted with the implementation of semiconductor components. In the first half of the $1960 \mathrm{~s}$, the production of germanium diodes and transistors was mastered there, and preparation for the production of silicon diodes and transistors was successfully launched.

Experts were also consulted with respect to the production of raw materials. The factory Aluminum Works in Skawina was producing polycrystalline germanium from 
germanium dioxide imported from western countries. TEWA itself was producing monocrystalline germanium. On the other hand, work was underway on launching production of high resistance polycrystalline silicon at the nitrogen plant in Tarnów. The targeted production capacity of Tarnów was to reach 5.9 tons per year in 1967. This was even higher than the forecasted demand for this intermediate product until 1970 .

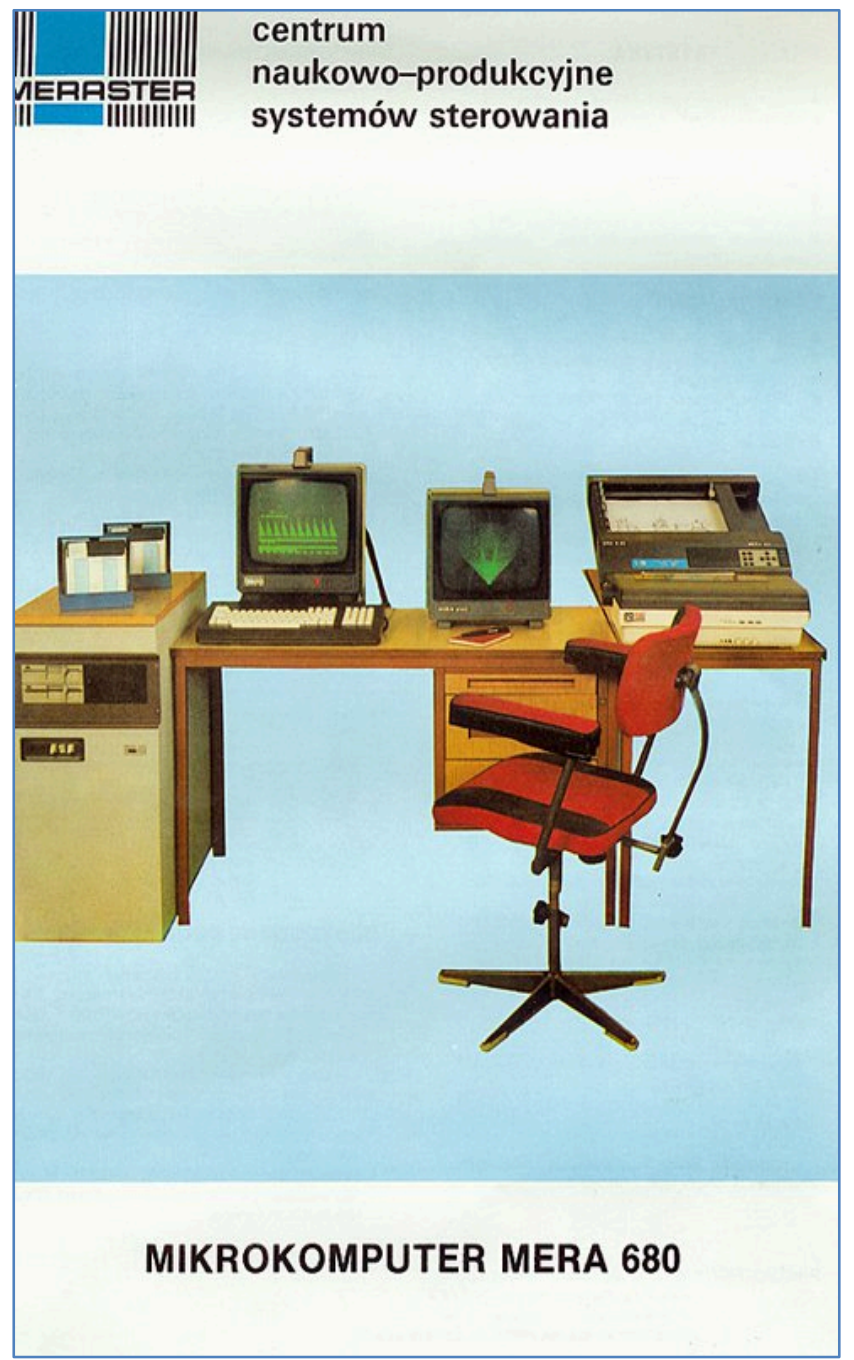

Fig. 1. In the 1980s, the Polish computer industry was able to export remarkable quantities of minicomputers to Comecon and especially to the Soviet markets, as in case of MERA minicomputers of series 60 manufactured in Silesia. Photo courtesy Piotr Fuglewicz. 
Moreover, in the mid-1960s the USSR provided technical assistance in mastering the technology of production of necessary chemical reagents, including hydrochloric acid, nitric acid, hydrofluoric acid or graphite. However, attempts to master modern technologies of semiconductor components production intended to operate on higher frequencies - i.e., epitaxial, planar and epi-planar technology - failed [48].

At the end of August 1964, a Polish delegation conducted extensive consultations with partners from the USSR, especially with the Committee for Electrical Engineering, Committee for International Cooperation, Committee for Black and Color Metallurgy, Committee for the Chemical Industry, etc. They visited the Tomilińsk electronics plant near Moscow and became acquainted with the technology of manufacturing semiconductor diodes. The subject of the visit was also to obtain further assistance from the USSR on the development of the Polish semiconductor industry, together with related branches of the chemical and metallurgical industries, in the years 19641968; in the first stage, the supply of equipment, semi-finished products like silicon piles, germanium transistors, silicon diodes, etc. and raw materials necessary to launch production in Poland, was envisaged [49].

In 1965, the heads of the Polish computer industry were invited to visit the leading Soviet scientific and production centers, including the powerful Cybernetics Institute of the Academy of Sciences of the USSR in Kiev. There, 1,700 employees developed, among others, the computers of the Ukraine and Dnieper series. They also visited the equally famous Institute of Mathematical Machines in Yerevan, were 1,200 employees developed, among others, the computers of the Nairi and Razdan series [50]. The visit lasted one month and included also trips to the Central Economic-Mathematical Institute of the Academy of Sciences of the USSR in Moscow, the Computation Centre of Gosplan and to the Computation Centre of the Academy of Sciences of the USSR. ${ }^{3}$ The latter worked on the basis of BESM series machines, including a state-ofthe-art computer BESM-6, constructed in transistor technology at the Institute of Precision Mechanics and manufactured since 1965 for the next 20 years. In addition, Poles visited the Central Institute of Scientific and Technical Information in Moscow (the so-called WINITI), as well as a huge S. Ordzonikidze Counting Machinery Factory in Minsk, where computers of the Minsk series were produced, and a smaller factory of Counting Machines in Vilnius, origin of the Ruta series computers. The Polish delegation held a conference with the head of the State Committee of Science and Technology of the USSR W. Kirillin, and with the officials of the Ministry of Radio Engineering Industry. However, the solutions applied in the famous Ural computer series computers, manufactured in the computer factory in Penza, were restricted from the Polish delegation. ${ }^{4}$

Poland was particularly interested in obtaining licenses from the USSR to produce line printers, ferrite core memory, magnetic drum (memory) heads, adapters and other components, as well as to purchase analogue computers, laminators and paper perfo-

\footnotetext{
See Kitov, "On the History of Gosplan," this volume.

4 For more information on Ural, see Smolevitskaya, "The Engineering Heritage of Bashir Rameev," this volume.
} 
rating machines. It was also planned to arrange cooperation of Elwro with the Counting Machinery Factory in Minsk and with the Institute in Yerevan.

However, during this visit, the Polish delegation discovered that the USSR lagged far behind the U.S. in terms of computer adaptation in the wider economy:

in the USSR, no electronic data processing system for the needs of business management has yet been set up. This is reflected, among other things, in the fact that mathematical machines are burdened with $90 \%$ of technical and scientific calculations on a national scale, and only with $10 \%$ of economic calculations.

Such a situation, when one considers the circumstance of the planned economy, which depends on precise forecasts and economic calculations, must have appeared kind of absurd to Poles [50].

There were several visits of Polish delegations in the Soviet factories and institutes following in the second half of the 1960s and the first half of the 1970s [51]. Polish specialists were invited into freshly modernized facilities like the Lviv Elektron television factory. In the early 1970s, the advanced automated control system for streamlining the industrial processes, so-called MISC, was installed and supervised there by the famous Institute of Cybernetics lead by Viktor Glushkov [21].

Eventually, Polish authorities were convinced by the representatives of the Soviet Planning Commission and of the Ministries of radio-technical and electronics industries to join the co called Riad series in December 1969. With much greater effort, Polish experts also made concessions, as it was the case the other remaining members of Comecon. ${ }^{6}$ Negotiations lasted for nearly two years prior to this agreement because of the fierce opposition of Elwro. Elwro was so satisfied with the recently obtained ICL architecture, which yet was allowed to be further developed not as a primary but barely as a secondary path (next to the primary IBM 360/370 architecture based Riad 30) Later, Riad 32 and Riad 34 followed in the course of the 1970s. The decision was a great disappointment for the team of Elwro engineers, but finally resulted in quite good products like the third generation Odra 1305/1325 and its military versions. These were acknowledged as very reliable part of radar systems by Czechoslovakia and states which imported their computers from PPR. Therefore, the Riad/IBM series, although being developed simultaneously for Polish and British computers, could be nowadays perceived as an additional positive incentive for Polish computer market that brought IBM standards to Polish scientists and manufacturers - even through the Eastern doors [43]. The Polish computer industry was continuing its cooperation with Soviet institutes over the 1970s and 1980s [52-53].

\section{Third Path: Stealing in the West in the 1970s and 1980s [54]}

As historians do not have access to the files of Soviet intelligence, we have to rely on documents produced by states associated in the Warsaw Pact to assess the impact of intelligence operations on Comecon's computerization. In many respects, they reflect

5 See also Kitova and Kitov, "Anatoly Kitov and Victor Glushkov," this volume.

6 See Schmitt, "Socialist Life," this volume. 
Moscow's point of view. The first significant operations of Polish intelligence's branch being addressed to the acquisition of scientific-technical documents and smuggling of embargoed equipment dated back to mid-1950s. After a serious defeat in 1961, when defection of a high-ranking officer escaped to U.S., it gradually recovered throughout the decade. Receiving substantial governmental support, financially and personally, in the early 1970s, it thrived along with Poland's entering global markets and the massive purchase of commodities, licenses and taking out loans. During the 1970s, intelligence proved to be able to bypass CoCom's embargo by bribing not only West European, but also U.S. and Japanese, companies. STI recruited agents with access to devices, especially testing equipment, components like memory disks and documentation, for example of assembly lines. By the end of the 1970s, the Polish computer industry included over a dozen of factories benefiting from covert operations.

The way of assimilating IT by communist Poland did not differ much from the way it was going on in USSR. It was namely a smart combination of legal measures like the use of trade agreements, official scientific-technical cooperation with OECD members, United Nations/UNCTAD/UNESCO programs for technical assistance, scholarships founded by Humboldt and many others and illicit operations. Those latter were run with help of intelligence assets like bribing or blackmailing officials and employees, establishing fake intermediating companies, smuggling devices via private channels, obtaining false end-user certificates, bypassing embargo via neutral and developing countries. Therefore, over many routes MSI- and LSI-technology, as well as specific types of computers along with peripheral devices, came to Poland. This holds true for mainframes, minicomputers, and later PCs.

Electronics and automatic control solutions appeared to be crucial fields of arms race and Cold War rivalry since the very beginning. Therefore, CoCom regulations covered many electric and then electronic items and components at the latest from the late 1950s ${ }^{7}$ [30, 55-56]. With the "National Security Decision Memorandum" no. 247 from 14 March 1974 entitled "US Policy on the Export of Computers to Communist Countries," President Richard Nixon approved new export guidelines. According to them, the USSR was excluded from importing significantly powerful western computers "détente notwithstanding" [57]. Two years later, J. Fred Bucy, executive vicepresident of Texas Instruments and chair of a 15-member task force composed of high officials from the Department of Defense and private firms, submitted the so-called Bucy Report. It distinguished between "active" and "passive" technology transfer mechanisms applied by the Soviet Union. "Active" - regarded as the most effective form of intercept - involved close and frequent personal contact between a "donor" and a "receiver"; for example, purchasing turnkey factories, licensing accompanied by an extensive teaching effort and joint ventures. "Passive," far less effective forms, were trade exhibitions, product sales without operating and maintenance information,

7 Electronic measurement equipment and the electronic devices are mentioned at least in the lists from Great Britain in the years 1954, 1958, 1960, 1961, 1962, 1964, 1966, 1969, 1972, 1976, 1980, 1985, (1987 access denied), 1989, 1990, 1991, 1993. Zob. http://evansresearch.org/cocom-lists 
and commercial literature. The report distinguished also between "evolutionary" and "revolutionary" advances. The first were improvements made routinely, whereas the latter were "quantum leaps." Therefore, they should be strictly protected "in order to prevent an adversary from making significant gains in a short period of time without having to incur the costs of research and development" [58]. Coming from those considerations, controls were placed on networking and signal processing software, image processing software, artificial intelligence, CAD, and CAM in mid-1984.

Despite that sophisticated legal instrument of restrictions during the five-year plan from 1976 to 1980, the KGB and GRU managed to obtain around 150,000 operational information documents on electronics, informatics, telecommunication, energy, aeronautics and many other branches in Western Europe [59]. It was estimated that the USSR saved 100,000 person-years of scientific research over those 5 years. During the 1970s, the Soviets acquired illegally 2,500 pieces of microelectronics manufacturing equipment and their intelligence services delivered approximately $6,000-10,000$ pieces of various hardware and 100,000 documents annually. In order to collect data from open sources, science and technology officers and their agents were visiting conferences, submitting proposals for scholarships and internships, etc. In order to obtain embargoed equipment and components, so called diverters-for-hire were spotted: they were contractors (brokers), who were not disciplined like agents and did not enter into long-term relationships with intelligence but rather came across with $\mathrm{KGB} / \mathrm{GRU}$ only once in their live for one certain transaction or sometimes a couple of transactions. More regular contractors were working for negotiated fees or were receiving commission, for instance, 10 percent of equipment purchase price or etc. [60].

Soviet setbacks in computing were at least partly balanced by hyper activity of the intelligence service. Referring to the CIA's assessment on the duality of Soviet industry, Michael Mastanduno claims that "the Soviets had effectively combined legal purchases with illegal acquisition of Western technology and equipment to achieve significant benefits across a wide range of military systems and to save hundreds of millions of dollars in research and development costs" [58].

After the political shift in Poland in the late 1970s, a new administration under Secretary Edward Gierek extended and institutionalized clandestine procedures. Science and Technology Intelligence officers massively purchased necessary microelectronic technology on the "black market": technical documentation and user manuals for mainframes, minicomputers and PCs, as well as software solutions, components, hardware or entire assembly lines. Hundreds of companies had been targeted, predominantly in the U.S., Japan and in Western Europe: RCA, Fairchild, Texas Instruments, CII, ICL, Siemens, AEG-Telefunken. Initially, smuggling commodities as well as money transfers had been conducted over fake companies established in EFTA countries. After tightening of the US-American embargo in the beginning of the 1980 s, though, new channels over ASEAN territory were explored.

"Black market" operations were not the sole occupation of Science and Technology Intelligence's Division III (later renamed to VI), responsible for IT. Officers were tracking, assessing and evaluating activity of the leading initiatives, think tanks, producers and users of advanced IT worldwide. During the 1980s, the scope of that surveillance covered, for example, the European Strategic Program on Research in IT, 
the American Semiconductor Research Corporation, or Japan's famous Ministry of International Trade and Industry and last but not least the Indian National Informatics Center. Polish intelligence officers exploited their covert positions in trade agencies or facilities for Research and Development and attended international computer shows and conferences as "Comdex" or "Logic."

Though numerous vital technologies, intercepted by intelligence, had been applied for instance in automating the assembly lines of the Polish automotive industry or in shipyards, one has to emphasize that the Polish economy with its commercial requirements was not the only beneficiary of the intelligence operations. Selected tasks were performed in favor of the military complex, as for instance in the case of Far Looking Infrared technology used in thermal imaging cameras, sensors and other detecting, targeting and aiming devices. The other important recipient was the Ministry of Internal Affairs itself, which was looking for the system of protection against emanating spurious transmission, i.e., so called Tempest. Probably the most critical incentive for the security service to get access to embargoed hardware and software were requirements of communist government to improve surveillance and data gathering on Polish society (an example makes clandestine acquisition of terminals produced by Honeywell-Bull company, and used for hosting the Polish Common System for Registration of Population - PESEL in the 1970s and then 1980s). Another crucial reason for interest in computers and data processing was maintaining and developing capabilities in both cryptology and cryptanalysis in civil and military special services [61].

There are excellently preserved annual reports of Polish Science and Technology Intelligence accessible in the archive of IPN for researchers, which enable us to get insight into the outcomes of their activity in the domain of computers [62-63]. In 1970, the Ministry of Internal Affairs established an undercover proxy of intelligence that was operating from within the Ministry for Machine Industry. It was a team of several officers who were officially employees of the machines ministry's Department for Foreign Relations. In fact, they were charged with the task of targeting interesting foreign managers, companies, R\&D centers and governmental institutions that came across Polish officials during business negotiations or scientific cooperation.

Summing up the scope of interest of several hundred operations launched by intelligence during 1970-1989, it has to be stressed that Polish Science and Technology Intelligence was able to fulfill almost all types of requirements from Polish industry and Research and Development. The exact number of operations is hard to figure out, but one may assume with high accuracy that it is close to 500, over the mentioned 20 years period of time:

- purchasing embargoed mainframes, minicomputers and later PCs on the black market in small quantities

- purchasing embargoed testing and measurement equipment

- intercepting classified know-how in the form of technical documents, blueprints, patents etc., that enabled reengineering entire assembly lines

- providing big quantities of embargoed components as memory disks, magnetic tapes, and various peripherals, especially printers 
- signing up long-term fake contracts, including false invoices and false end-user certificates, that resulted in smuggling of entire assembly lines to Poland for low, medium and finally large scale of integration circuits

- providing follow-up information on western works on "internet." The security service's involvement in the works on "infostrada" - a Polish concept resembling the American ARPANet [64] in the 1970s and 1980s - deserves for sure a separate historical approach [65]

- Other innovative applications of computers, like artificial intelligence, etc.

The major beneficiary of the intelligence operations during those two decades in the area of computers and in a broader sense microelectronics were factories and R\&D facilities of Elwro in Wroclaw and CEMI (former TEWA) in Warsaw. The CEMI complex was established in the mid 1960s for manufacturing integrated circuits and was fully operational by the beginning of the 1970s. Technologies of mid-, large- and very-large-scale-integration were obtained unofficially mostly in the U.S., Japan, West Germany and Great Britain from such companies as Kulicke and Soffa, Redac, Kasper, Balzers, Macrodata, ASEA, Electromask, Eberle, Siemens, Philips, Sentinel, Silvar Lisco, Intel or Fairchild-Schlumberger. A large part of intercepted material referred to IBM 370/155, IBM communications processors types 8100/8725, $3705 / 3725$ and was used in the Riad program [66-68].

During the 1970s and 1980s, approximately US\$50-100 million were transferred from industry and R\&D via secret bank accounts of Science and Technology Intelligence in Poland and abroad to agents and fake companies that sold embargoed goods in the area of microelectronics. However, most of those commodities, although of so called dual-use nature, were ordered not by the Polish military but for the civil economy.

Though the direct financial benefits of illegal acquisition of microelectronics were alluring for Polish government, there were also huge disadvantages. There was no guarantee, so that troubles with illicitly purchased components or devices inevitably involved additional consulting of foreign specialists. They had to be recruited as agents or simply hired only once for money reasons, brought to Poland in a risky operation, and obviously payed high reimbursements. Moreover, as the Soviets experienced many times, the CIA or other American special services were sometimes able to track down clandestine contracts on U.S. or West European soil. They intercepted cargo and damaged it in a very smart way so that the fault became possible to identify only after booting acquired devices or components in the facility of the smuggler, for instance in Poland or the USSR [69].

By enforcing the Export Administration Act by the administration of President Jimmy Carter in 1979 as a response to the Soviet involvement in Afghanistan, U.S. authorities exacerbated the control of international trade with goods, especially those embedding advanced microelectronics. After General Wojciech Jaruzelski's government introduced martial law in order to crush "Solidarnosc" in Poland in late 1981, the Polish People's Republic was additionally punished by Ronald Regan's administration. The U.S. removed the so-called Most Favored Nation status from bilateral trade relations between the two countries. All those political tensions contributed to 
the shift of proportions between official and clandestine ways of high-tech acquisition by the PPR. In opposite to the 1970s, when legal channels prevailed over smuggling, in the 1980s it was the intelligence activity that was growing rapidly, making official channels usually fruitless and redundant. That phenomenon quickly made the Polish Ministry for Machine Industry, responsible for implementation of computers in domestic economy, entirely addicted to the secret influx of data-processing know-how and equipment. Black market purchases involving IT-goods were consuming on the average several millions of USD annually.

Next to Western Europe, the U.S. and Japan there was a fourth interesting player emerging on the horizon in the early 1980s: China. It was both target and partner, looking from the perspective of PPR's intelligence gathering on computers. That ambiguity resulted from the fact that in the 1980s Beijing was enjoying a U.S. and European differential policy in the area of science and technology similar to the special status granted to Poland and Romania in the 1960s in order to keep those countries away from USSR. Nevertheless, in case of Poland, many crucial technologies remained under restriction to be shared despite of a friendly approach in Washington. Based on its own experience as a privileged communist country, Polish authorities strove for cooperation with China, knowing that it would enable access to very-largescale-integration technology via the Shenzhen Special Economic Zone. That kind of thinking turned out to be very reasonable. On the eve of the 1990s, Polish intelligence was already negotiating a deal worth US\$100 million with the Chinese [54].

Though we do not have many declassified documents confirming the Polish S\&T information exchange with other communist countries in the East/South-East Asia region, at least contacts with the Democratic Republic of Vietnam and also with North Korea can be proved. For instance, in 1987, representatives of the Polish computer industry in the UNITRA holding, accompanied by intelligence officers, initiated talks with North Korean companies Undok Group, Korea Jeil Equipment-Export and Import Co. During the meeting in Pyongyang, Koreans proposed intelligence assistance in approaching Japan and U.S. companies. Polish officials were interested in photolithography, ion implementation, and testing equipment with regard to VLSI [70]. 


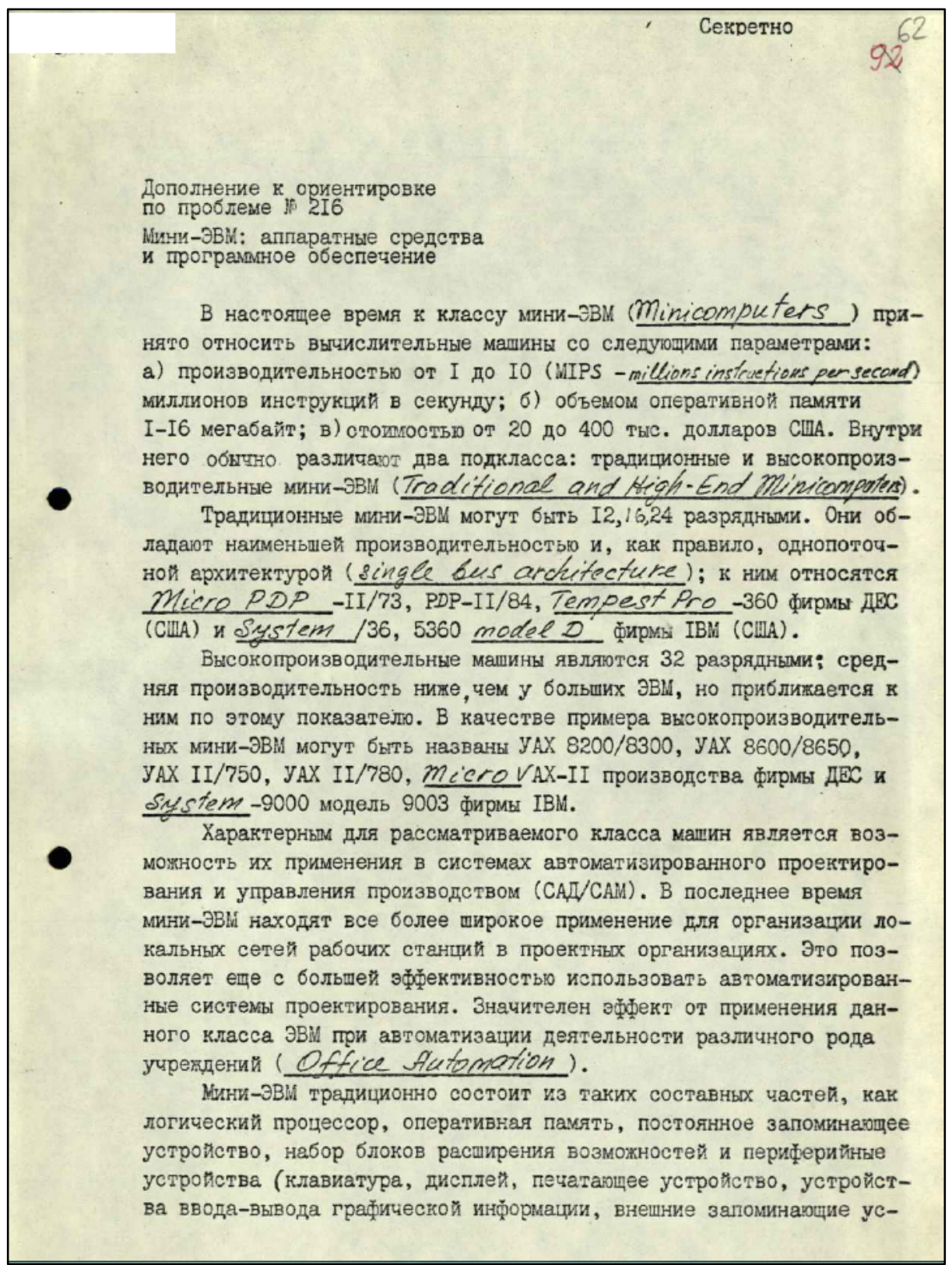

Fig. 2. Example of declassified cables exchanged between Polish and Soviet intelligence services cooperating in the area of embargoed software. In this analysis the KGB informs Polish partner about the development of minicomputer market in USA and Western Europe. Source:

AIPN Warsaw 


\section{Fourth Path: Intelligence Sharing with Warsaw Pact Partners in the 1980s}

Next to the operations authorized by the Polish government or party leadership, Polish Science and Technology Intelligence and in effect the entire economy profited from the achievements of spy networks working for the remaining Comecon countries. Intense information exchange started at the latest in the course of the 1960s, though some liaisons between individual STIs existed already in the second half of the 1950s. During the 1970s and in particular the 1980s, Polish Science and Technology Intelligence shared its knowledge with partners. This ranged from KGB's foreign intelligence, the extremely successful Markus Wolf's East German "Hauptverwaltung Aufklärung" (HVA), to other intelligence services, especially Czech, Bulgarian and Hungarian. Those ties certainly included reciprocity. A constant stream of western user manuals, blueprints, technical documents, and confidential analysis flowed from Moscow, East Berlin or Prague to Warsaw year by year. However, that interlinked system was not faultless. Contacts on the level of intelligence services implied rivalry, mistrust, and sometimes deception and spitefulness. It occurred that information vital for one country had been hidden by another one in order to impede progress in area that underwent severe competition inside of Comecon [71].

Until the early 1980s, the U.S. government was seemingly unaware of the extent (and sophisticated methodology behind) to which the KGB was penetrating into the Western economies and especially scientific circles, though there were many indications and clues confirming advanced espionage activity. The breakthrough came with French intelligence's recruitment of the high-ranking employee of KGB's Science and Technology Intelligence Vladimir Vetrov, codenamed Farewell. French intelligence handed over documents received earlier from Vetrov to the CIA in the second half of 1981. In 1983, the Soviets learned about the treason and in 1985, the French public and in the world were informed about the affair. "Farewell" disclosed to French and then American intelligence the names of more than 200 staff personal employed in the Soviet Science and Technology Intelligence branch abroad in ten western countries, and approximately 100 sources recruited in favor of line X (as Soviet STI abroad was codenamed). In following months and years, western countries expelled hundreds Soviet diplomats. It was the greatest disaster for KGB and GRU since the beginning of the Cold War. It quickly turned out that line X fulfilled twothirds to three-fourths of the requirements from Soviet industry and Research and Development [57]. According to a CIA memorandum from 1985: "in recent years, the surrogates among the East European intelligence services possibly have been more successful than Soviet intelligence against priority defense technologies in the United States" [60]. Cases of very successful spies working for Polish intelligence like William Bell and James Harper confirm this notion [72]. East European services had considered success not only in the United States but elsewhere because, in comparison to the Soviets:

They are generally perceived as a lesser threat than the Soviets; they often may not be perceived as operating in a surrogate role; in some countries, including the United States, they operate under less sever travel restrictions; some, especially the Czecho- 
slovaks and the East Germans, probably find it easier to operate in the West European cultural and commercial climate. [60]

The contribution of communist allies to the joint Science and Technology Intelligence undertakings of Warsaw Pact rose enormously after the Farewell affair. Throughout the 1980s, Polish Science and Technology Intelligence was sharing annually several dozens of computer solutions like batches of technical documentation, user manuals, western think tanks' analysis etc. with its partners in Warsaw Pact Treaty [73]. Reciprocally, the Soviets and GDR and to a lesser extent, other partners, passed on to Poland their achievements in the field of intelligence. One has to emphasize that mutual and unilateral confidence was limited because each intelligence service complied with national interests and domestic computer markets (for statistics, see Appendix). Based on the operation case files covering the last five years of the PPR, one can easily obtain an extensive overview over the scope and content of exchanged material. Altogether, hundreds of secret transfers can be identified.

For instance, during 1984-1985, Polish intelligence received from its East German counterpart various utility programs and operating systems for the mini-computer PDP-11/73 produced by Digital Equipment Corporation. Documents on programs like RSTS/E v. 7.2., DECNET/E v. 2.0./2.1 were delivered in the form of textbooks and recorded tapes. The Polish government - via intelligence - paid several tens of thousands USD. Software was not intended to be used in DEC computers installed in Poland but was considered as vital aid in developing local minicomputers and programs, based on DEC architecture and logic. The long-term objective of the Polish government was to speed up the development of its own hardware and software, and moreover to export in the near future Polish products to the Comecon markets [74]. In 1988-1989, Polish intelligence reciprocated when GDR's Hauptverwaltung Aufklärung addressed Poles with request for access to know-how on photolithography of Intel Corporation's processors 80C86, furthermore on microchips. Calculated costs amounted to about US $\$ 700,000$ (processor) and US\$600,000 (RAM). Polish Science and Technology Intelligence exploited its assets in West Germany and Japan and was able to surpass expectations of Hauptverwaltung Aufklärung [75].

Among the most relevant objects for the Division VI of the Department I in Polish Ministry of Internal Affairs there were various R\&D programs launched by the European Economic Community (EEC) in the mid 1980s. The path was paved already by the European Strategic Program for Research in IT (ESPRIT) launched in 1983. In this program, western companies such as French Thomson or West German Siemens cooperated in order to unify computer systems and build an integrated data transfer network. By exploiting synergies, the full competitiveness of ESPIRIT with the U.S. and Japan was planned to be reached in the first half of the 1990s. The program had a budget of ECU 1.5 billion, which at that time had a rate close to that of today's euro, for its first five years of operation [76].

In March 1985, Mikhail Gorbachev took over the Soviet Union and started his reforms. The so-called Complex Program for the Progress in Science and Technology 2000 (CP 2000) was announced during the extraordinary session of Comecon in Moscow in December 1985 after three years of intensive preparations [77]. It was not the first time that Comecon states tried to coordinate their Research and Development 
efforts. A similar program, though launched in utterly different circumstances, was initiated in 1971 and failed, according to Comecon's own assessments. The overwhelming bureaucracy was blamed for the setback, while another reason was the demise of détente in the late 1970s [78].

Though there were altogether five areas and 93 sub-projects covered by the CP 2000, one was placed on the top of the list: electronics and automatic control. Those two branches impacted every part of economy much more than chemistry, biotechnology or heavy industry did. Regarding the progress in electronics, Soviet authorities, which presumably contributed to the final version of the program in the greatest degree, distinguished development in following aspects:

1. Supercomputer capable of at least 10 million operations per second, based on artificial intelligence technology

2 Mass production of PCs along with utility programs applied in management, education, computer learning, and for leisure purposes

3. Joint system of digital information transition and significant enlargement of telecommunication infrastructure, the so called TELE JS Riad

4. Fiber optic communication. Indeed, Poland achieved impressing scientific results in fiber optic communication during the 1980s but eventually failed to introduce them into development and production

5. New satellite communication systems and long-range TV transmission

6. Measurement and control equipment

7. Very-large-scale-integration technology.

In the domain of automatic control, there was one major target on the horizon: improving Computerized Numerical Control (CNC) of assembly lines and transforming plants into so-called flexible manufacturing systems. It implied Computer Aided Design and Manufacturing (CAD and CAM) solutions, robots and its components like hydraulic, pneumatic, electronic parts as well as automated loading and unloading equipment etc. [78].

According to West German analyst Henrik Bischof, CP 2000 manifested a third stage of integration efforts within socialist camp: assuming that the first was of economic nature (Comecon), the second of military nature (Warsaw Pact) [77], the third one being of scientific-technical nature. Exactly as the first and the second concept Moscow came up with, also the third endeavor was not inspired from within the communist camp but came as a countermeasure to the western concept of scientifictechnical integration. Similarly, Comecon was an alternative to the Marshall Plan in 1949; the Warsaw pact was a counterpart of NATO in 1955. CP 2000 was meant as Comecon's response to European Research Coordination Agency and its massive financial support for R\&D initiatives in innovative disciplines of science and fields of technology, especially automated control and electronics [79].

Polish Science and Technology Intelligence was charged with acquisition of knowhow for domestic needs and in favor of allies, especially of the USSR. For instance, at the beginning of 1988, the Polish Science and Technology Intelligence's headquarters sent guidelines to selected officers in embassies abroad regarding the scope of interest of EEC countries and companies from beyond the EEC involved in Eureka program. 
The intelligence proxy in Rome was asked about Eureka's leading projects and subtopics, $R \& D$ centers involved in those projects, especially businessmen, managers and researchers and engineers with ties to Poland [80]. The responses from intelligence officers abroad came usually after several weeks as the example of Vienna proves. The officer there put emphasis on the most promising - according to his assessment initiatives the Austrian entities were involved in, namely Flexible Automatisierte Montagesysteme (FAMOS) coordinated by Oesterreichisches Forschungszentrum in Seibersdorf. The officer stressed that seven countries participated in the program, among them West Germany, France, Italy and Great Britain. He described in detail individual research topics carried out in the framework of FAMOS in various companies and research centers, along with providing information about scientists and managers responsible for those topics [81].

Though the focus of information shared in the framework of Comecon intelligence community was put on OECD countries, China's coming out as a user, then producer of American computer technology in the early 1980s shifted KGB's attention as a "trend setter" in the area of intelligence gathering to Southeast Asia. In March 1986, the KGB reported to its Polish counterpart about a semiconductor assembly line in Shanghai where integrated circuits licensed by Japan were going to be manufactured soon. Soviet intelligence passed on to Polish intelligence a complete technical documentation of the assembly line along with sketches of factory buildings [82].

Taking into consideration bad Soviet-China diplomatic relationships dating back to the early 1960s, one can ask whether the KGB was trying to make any use of sometimes much better ties maintained with China by Comecon states in order to intercept scientific-technical intelligence.

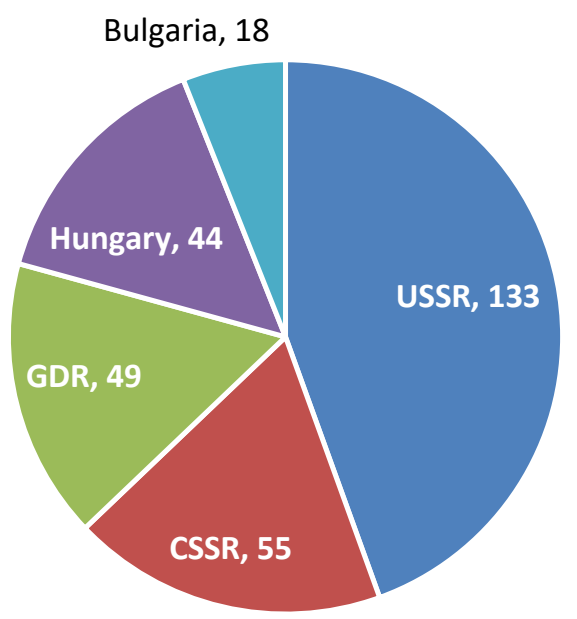

Fig. 3. Solutions received during 1987 from individual intelligence services by Polish STI in the area of microelectronics and software. Source: AIPN Warsaw 


\section{Conclusion and Further Prospects}

Poland attempted to get access to cutting-edge computer technologies through many and various doors. The ones that were legal involved cooperation with senior partners - the USSR and remaining partners from Comecon. CoCom's embargo handicapped, however, the entire Comecon so that every member tried to acquire know-how via illegal channels, usually organized and managed by the individual intelligence services. Poland was also guilty of using those methods, despite a distinct privileged position in commercial relationships with the U.S.

Exactly at the same time when pioneers of the Polish foreign intelligence arrived at Paris, London and Bern, domestic Research and Development programs coordinated either by the Warsaw based Institute of Mathematical Machines or by Wroclaw-based Elwro's experimental unit were initiated. Moreover, a new governmental body called the Committee for Science and Technology sent its representatives to Polish embassies in western countries with the task of tracking local computer markets and setting up contacts with electronics companies prone to cooperate across the Iron Curtain, despite the embargo on dual-use items.

The second channel of know-how transfer was the one set up between Poland and USSR. Both countries signed on to an agreement about scientific-technical cooperation back in 1947, but until the mid-1960s, computer technology was rather beyond the agenda of mutual ties. Know-how exchange followed by trade agreements accelerated only after 1964, partly thanks to the new established Commission for Radiotechnique and Electronics in Comecon.

Soviet technical assistance for its communist allies was, however, limited. Moscow was sharing its precious knowledge reluctantly. Perhaps (this is supposition) Soviet authorities was purposefully pushing Poland and other countries into the arms of western sellers. By that occasion Soviet engineers could obtain access to know-how sold by the West to its "satellites states" which otherwise was beyond the range of USSR scientists due to embargo and security measures. Nonetheless, Polish officials and experts failed to persuade the Soviet Planning Commission to take advantage of Poland's positive experience with ICL architecture and use it as a model during the works on a joint Comecon computer standard (Riad).

Eventually, Poland officially joined Riad in December 1969. The entire concept was at that time in statu nascendi, but by the end of 1970 it became clear that it would be the architecture of IBM 360 and Small Scale of Integration to make a pattern for the future Comecon computers of various capacities. Elwro chiefs were devastated because Polish industry was not prepared for "reverse engineered" IBM. In order to meet the deadlines scheduled by Soviet authorities for the introduction of R-series in the entire Eastern Bloc and in individual countries, the Polish government decided to pass on some tasks - it was charged within the framework of Comecon community to its intelligence service.

One has to emphasize that the USSR successfully reverse engineered not only mainframes of IBM series 360/370 as the Riad family in the 1960s or the minicomputers DEC PDP-11/73 in the 70s as Elektronika 60, but also managed to build clones of 8-bit Apple II as Agat-1, 8-bit Intel Corporation processor 8080A as 
KR5801K80A, Texas Instruments Integrated circuits 5400/7400 family as Logika-2, 133/155), and even 16-bit IBM-PC with Intel processor 8086 as Iskra 250. Those implementations, based on intelligence data, seem to prove the reliability of STI as a factor in the economy, but only as vehicle for know-how transfer. Communist intelligence - and Polish STI showcases it - cannot replace economic instruments and the entire environment of the western world that includes free market, commercial incentives and competition between enterprises. The planned economy with its all organizational faults and bureaucratic burdens turned out to be too ponderous to take advantage of intelligence operations. Kristie Macrakis made similar observations in regard to GDR's STI [84]. Though the STI was itself efficient, its impact on Polish computer industry was not as significant as legal cooperation with the Soviet partner.

Flashy spy operations together with successful bribery of some leading capitalistic companies or their employees enabled the Polish government a constant updating of the worldwide trends in I.T. However, the intelligence service was incapable of making a decisive impact on the Polish microelectronic industry, with a result that along with the Research and Development sector - constrained by the rules of planned economy - failed to catch up with western producers and inventors.

Moreover, Polish intelligence - like its counterparts in the GDR, Hungary etc. - intensified its cooperation and information sharing with KGB's foreign intelligence service. As a result, not only ties to the Western world were organized twofold on and under the table, but also relationships with allies in Comecon were arranged in two dimensions.

Was the investment in illegal activity worth it? Apart from expenditures on training and employment of tens of intelligence officers working on overt and covert positions in- and outside of the country, there was also the need for financing sophisticated operations abroad. This often included setting up fake companies. Moreover, the intelligence service had to keep up hundreds of secret collaborators, consultants and some other auxiliary staff. Those mentioned experts were responsible for defining requirements for the Polish science and industry. After successfully transfer the technology, they evaluated the documents, patterns, samples and devices obtained by STI. Finally, the "legalization" of intercepted solutions followed by submitting Polish patents and implementing them in the Polish plants. The phenomenon of Science and Technology Intelligence becomes even more fascinating when it comes to payment for Polish agents in the area of I.T. - probably the most money-consuming aspect of black-market operations. It seems that the financing of those purchases was almost entirely covered by the funds earmarked for the Research and Development in the individual ministries that "ordered" a certain solution. It means that sometimes the money invested in STI operations had to be withdrawn from the direct R\&D initiatives. The risk emerged in both cases. Domestic R\&D works could have ended up with nothing or with outdated solutions, but at the same time clandestine operations could have also failed. For instance, in the 1970s several illegal shipments of cargo from USA had been intercepted by US customs. While the other time black market contractors cheated Polish officers by selling faulty or broken equipment. 
On the other hand, there were of course significant benefits generated by the Science and Technology Intelligence - savings resulted from know-how "for free" transmission and so called "reverse engineering" without any licensing costs.

Eventually, the demise of communism in the PPR and subsequently in the USSR, along with the unexpected economic "assault" of U.S. and West European computer manufacturers, the lifting of the embargo and the emergence of free market rules, totally transformed the structure, needs and trajectories of development for microelectronics in now free Poland. For instance, Siemens took over control of Elwro. The case of Poland gives an excellent example of how schizophrenic the computer market in Comecon during the 1970s and 1980s was.

\section{Appendix - Statistics on Intelligence Gathering from 1987 to 1989}

By task (operation), the undertaking of intelligence officers is meant, officially registered in the intelligence data bases as task; it involves clandestine activity abroad, recruitment of informants, black market purchases, illicit money transfers and trafficking of documents and items; tasks were either company (IBM, DEC, Siemens etc.) or technology orientated (testing equipment, computers, peripherals); were often long-term lasting covering time span from couple of months up to several years.

By "solution" is meant: 1. blueprints, patterns, and complete or partial technical documentation allowing "reverse engineering" of: design, layout, construction of electronic device (mainly computers and peripherals) and components (memory tapes and hard disks, CPUs); 2. technological documentation of entire assembly lines (for instance VLSI); 3. software or its elements (assemblers, compilers, translators, utilities, operation systems, libraries), 4. Various automatic control, measurement and testing equipment, drivers, user manuals etc.

The data is selected and juxtaposed by the author. It originated from three extensive reports of STI's Chief covering all STI areas of activity. Some numbers below can be incoherent one to another.

Table 1. Efficiency of the Division VI of the Department I in the Ministry for Internal Affairs from 1987-1989. Scope of activity: intelligence gathering in the domains of IT, microelectronics, programming, automatic control systems etc.

\begin{tabular}{|c|c|c|c|}
\hline & 1987 & 1988 & 1989 \\
\hline \multicolumn{4}{|l|}{ Tasks } \\
\hline Tasks (operations) accomplished: & 17 & 2 & 14 \\
\hline Tasks (operations) canceled & 3 & 5 & 16 \\
\hline Tasks (operations) added & 7 & 9 & 14 \\
\hline Ongoing tasks (operations) by the end of the year & 50 & 52 & 36 \\
\hline \multicolumn{4}{|l|}{ Acquisition } \\
\hline Solutions received from the informants (agents) & 154 & 293 & 306 \\
\hline Solutions received from allied intelligence agencies & 299 & 198 & $?$ \\
\hline
\end{tabular}




\begin{tabular}{|c|c|c|c|}
\hline Solutions received from other sources/institutions & 23 & 28 & $?$ \\
\hline $\begin{array}{l}\text { Solutions obtained in the framework of tasks (opera- } \\
\text { tions) and intel-interchange - total }\end{array}$ & 476 & 519 & $?$ \\
\hline \multicolumn{4}{|l|}{ Dissemination } \\
\hline $\begin{array}{l}\text { Solutions provided to recipients (ministries) in civil } \\
\text { domain }\end{array}$ & 265 & 81 & 224 \\
\hline $\begin{array}{l}\text { Solutions delivered to military and security service } \\
\left(\mathrm{C}^{3}, \text { cryptology }\right)\end{array}$ & 50 & 83 & 13 \\
\hline Solutions shared with partner intelligence agencies & 66 & 167 & 46 \\
\hline Other recipients & 16 & 16 & 0 \\
\hline \multicolumn{4}{|l|}{ Evaluation } \\
\hline $\begin{array}{l}\text { Solutions evaluated by experts by the end of the year, } \\
\text { including solutions delivered in the previous year(s) - } \\
\text { total }\end{array}$ & 113 & 82 & 132 \\
\hline $\begin{array}{l}\text { Evaluated as complete solutions, ready to implement } \\
\text { (to manufacture) }\end{array}$ & 4 & 1 & $0(?)$ \\
\hline $\begin{array}{l}\text { Evaluated as solutions partly ready to be introduced in } \\
\text { production }\end{array}$ & 2 & 1 & $0(?)$ \\
\hline $\begin{array}{l}\text { Evaluated as valuable solutions not ready to be im- } \\
\text { plemented/the need for further R\&D }\end{array}$ & 78 & 50 & 56 \\
\hline $\begin{array}{l}\text { Evaluated as general know-how (informative but su- } \\
\text { perficial) }\end{array}$ & 23 & 25 & 75 \\
\hline Evaluated as valueless material & 6 & 5 & 6 \\
\hline
\end{tabular}

Source: AIPN, Ministerstwo Spraw Wewnętrznych, sign. 001912/5, statistical reports from January 1988, January 1989 and January 1990 for the Internal Intelligence Data Base, status: secret (tajne).

Acknowledgement. Research was funded by National Science Center (NCN), Poland, Project Sonata, Edition 13, No: 2017/26/D/HS3/00250.

\section{References}

1. Zarys historii elektroniki w Polsce, ed. Mieczysław Frącki et alia, Przedsiębiorstwo Innowacyjne MAJAX 2015.

2. Polska Informatyka. Wizje i trudne poczqtki, ed. Marian Noga, Jerzy S. Nowak, PTI, Warszawa 2017.

3. Władysław Gomułka, The Policy of People’s Republic of Poland, "Foreign Affairs", Vol. 38, No. 3, April 1960.

4. Spętana Akademia. Polska Akademia Nauk w dokumentach władz PRL, Vol. 1, ed. Patryk Pleskot, Tadeusz Paweł Rutkowski, Warszawa 2009.

5. Adam B. Empacher, Maszyny liczq same?, WP 1960. 
6. Slava Gerovitch, From Newspeak to cyberspeak. The history of Soviet cybernetics, The MIT Press Cambridge, Massachusetts - London 2002.

7. AAN, Ministerstwo Przemysłu Maszynowego 1967-1981, Inventory No. 1758.

8. AAN, Ministerstwo Hutnictwa i Przemysłu Maszynowego 1981-1987, Inventory No. 1757.

9. AAN, Komitet Nauki i Techniki 1963-1972, Inventory No. 787.

10. AAN, Urząd Postępu Naukowo-Technicznego i Wdrożeń 1985-1991, Inventory No. 2726.

11. RGAE, Sekretariat Soveta Ekonomicheskoy Vzaimopomoshchi 1949 - 1991 - Fond 561, Postoyannaya Komissiya Po Radiotekhnicheskoy i Elektronnoy Promyshlennosti, Opis No. $14,14 \mathrm{pp}, 32 \mathrm{~s} / \mathrm{pp}$.

12. RGAE, Postoyannoye predstavitelstvo SSSR pri Sovete Ekonomicheskoy Vzaimopomoshchi 1949 - 1988 - Fond 302.

13. Federal Archiv (Bundesarchiv) in Berlin-Lichterfelde.

14. Stasi Archive (BStU/Behörde des Bundesbeauftragten für die Stasi-Unterlagen) in Berlin.

15. Mirosław Milewski, Rola i Zadania wywiadu MSW, 1972, [in:] AIPN, sign. 01738/21.

16. Sprawozdanie Wiceministra spraw wewnętrznych dla Premiera i in. (projekt), September 1989, [in:] AIPN, sign. 02271/21, Vol. 23.

17. Marian Zacharski, Nazywam się Zacharski, Marian Zacharski. Wbrew regułom, Zysk i Ska, Poznań 2009.

18. Patryk Wasiak, Computing behind the Iron Curtain. Social Impact of Home Computers in the Polish People's Republic, „Tensions of Europe”, http://www.tensionsofeurope, eu/www/en/files/get/publications/WP_2010_08_Wasiak.pdf, last accessed 2018/09/28.

19. Bartłomiej Kluska, Automaty liczq. Komputery PRL, Gdynia 2013.

20. Kierunki rozwoju przemystu elektronicznego i teletechnicznego w latach 1966-1970, Warszawa, February 1964, [in:] AAN, Ministerstwo Przemysłu Ciężkiego, sign. 37/36.

21. Benjamin Peters, How Not to Network a Nation: The Uneasy History of the Soviet Internet, The MIT Press Cambridge, Massachusetts - London 2016.

22. Uzasadnienie uchwały Komitetu Ekonomicznego Rady Ministrów (KERM) w sprawie rozwoju radiokomunikacji ruchomej lądowej UKF w latach 1966-1970, 24 March 1966, [in:] AAN, KNiT, 787, sign. 10/52.

23. „Młody Technik” monthly 1950-1990.

24. „Horyzonty Techniki” monthly 1950-1990.

25. „Horyzonty Techniki dla Dzieci” monthly 1950-1990.

26. Informacja $i$ wnioski $w$ sprawie rozwoju technicznego pótprzewodników i podzespołów elektronicznych, Zespót Elektroniki i Telekomunikacji KNiT, [1966], [in:] AAN, KNiT, 787, sign. 10/52.

27. Załacznik nr 10/Tabela nr 1 i 2 - Założenia rozwoju techniki obliczeniowej do 1975 r., [in:] AAN, KNiT, 787, sign. 40/247.

28. Uzasadnienie projektu Uchwały Rady ministrów w sprawie zadań w zakresie mechanizacji $i$ automatyzacji przetwarzania informacji $w$ gospodarce narodowej $w$ latach 1966-1970, [1966], [in:] AAN, KNiT, 787, sign. 10/52.

29. Oscar Sanchez-Sibony, Red Globalization. The Political Economy of the Soviet Cold War from Stalin to Khrushchev, Cambridge University Press 2014.

30. James W. Cortada, The Digital Flood: The Diffusion of Information Technology Across the U.S., Europe, and Asia, Oxford University Press 2012. See also the articles of Chris Leslie and Martin Schmitt in this volume.

31. Department of State - Airgram from AmEmbassy Warsaw, Subject: License Application for an Oscilloscope consigned to Institute of Nuclear Science in Swierk, 17 December 
1969, [in:] NARA, Records Group 59, General Records of the Department of State, Central Foreign Policy Files 1967-1969, Strategic Trade Control, Box 1414.

32. Department of State - Telegram from AmEmbassy Warsaw, Subject: US Export to Poland of oscilloscope and spectrum analyzer, 14 February 1972, [in:] NARA, RG 59, General Records of the Department of State, Central Foreign Policy Files 1970-1973, Strategic Trade Control, Box 1548.

33. Department of State - Airgram from AmEmbassy Warsaw, Subject: Instruments for Polish National Bureau of Measures and Quality Control, 12 January 1967, [in:] NARA, RG 59, General Records of the Department of State, Central Foreign Policy Files 1967-1969, Strategic Trade Control, Box 1415.

34. Department of State - Telegram from US Mission OECD Paris, Subject: French Transistor Technology to Poland, 8 October 1969, [in:] NARA, RG 59, General Records of the Department of State, Central Foreign Policy Files 1967-1969, Strategic Trade Control, Box 1415.

35. Memorandum for Mr. Henry A. Kissinger The White House, Subject: French Desire to Sell Transistors Technology to Poland, 23 October 1969, [in:] NARA, RG 59, General Records of the Department of State, Central Foreign Policy Files 1967-1969, Strategic Trade Control, Box 1415.

36. Department of State - Airgram from AmEmbassy Warsaw, 30 June 1966, [in:] NARA, RG 59, General Records of the Department of State, Central Foreign Policy Files 1964-1966, Strategic Trade Control, Box 1441.

37. Informacja $i$ wnioski $w$ sprawie rozwoju technicznego pótprzewodników i podzespołów elektronicznych, Zespót Elektroniki i Telekomunikacji KNiT, [1966], [in:] AAN, KNiT, 787, sign. 10/52.

38. Wyciqg z instrukcji w sprawie zakresu działania, obowiqzków i uprawnień pracowników do spraw wspótpracy gospodarczej i naukowo-technicznej w placówkach zagranicznych PRL oraz zasad ich współdziałania z kierownikiem i poszczególnymi komórkami tych placówek - wprowadzonej Zarzqdzeniem nr 2 Przewodniczqcego Komitetu Wspótpracy Gospodarczej z Zagranica przy Radzie Ministrów z dnia 30 grudnia 1965 r., [in:] AAN, KNiT, 787, sign. 12/39.

39. KNiT - projekt: Wytyczne dla pracowników do spraw wspótpracy gospodarczej i naukowo-technicznej $w$ placówkach zagranicznych PRL $w$ zakresie współdziałania $z$ Komitetem Nauki i Techniki PRL, [15 December 1966], [in:] AAN, KNiT, 787, sign. $12 / 39$.

40. Piotr Lipiński, Geniusz i świnie. Rzecz o Jacku Karpińskim, JanKa 2014.

41. Adam B. Empacher, Wzrost ilościowy cyfrowych maszyn matematycznych $w$ niektórych krajach (stan dotychczasowy i perspektywy rozwojowe), Warszawa, 1965.

42. Uzasadnienie projektu Uchwały Rady ministrów w sprawie zadań $w$ zakresie mechanizacji $i$ automatyzacji przetwarzania informacji $w$ gospodarce narodowej w latach 1966-1970, [1966], [in:] AAN, KNiT, 787, sign. 10/52.

43. Barbara Maćkowiak, Andrzej Myszkier, Bogdan Safader, Polskie komputery rodzity się w ELWRO we Wrocławiu. Rola Wrocławskich Zakładów Elektronicznych ELWRO w rozwoju informatyki w Polsce, ed. Grażyna Trzaskowska, Wrocław 2017.

44. Department of State - Telegram from AmEmbassy Warsaw, Subject: Fairchild sale of integrated circuits technology to Poland, 27 June 1973, [in:] NARA, RG 59, General Records of the Department of State, Central Foreign Policy Files 1970-1973, Strategic Trade Control, Box 1548 .

45. M. Sikora, N. J. Pivovarov, Formirovaniye sovetsko-polskogo ekonomicheskogo sotrudnichestva $v$ oblasti elektronnoy promyshlennosti $v$ kontse 1950-1960-ye gody [in:] XXII 
Godichnoy nauchnoy mezhdunarodnoy konferentsii Instituta istorii yestestvoznaniya $i$ tekhniki im. S.I. Vavilova RAN 28 marta - 1 aprelya 2016 g., Moscow 2016.

46. Dopolneniye 2 - k kontraktu 7204/3 ot 3 marta 1960 goda na vypolneniye proyektnykh rabot dla stroitelstva proizvodstv poluprovodnikovykh materialov (monokristallicheskogo germaniya i kremniya) v Polskoi Narodnoy Respublike [1961], [in:] AAN, KNiT, 787, sign. 40/245.

47. Posolstvo Polskoy Narodnoy Respubliki - Byuro torgovogo sovetnika do tov. NIKITINU A.E. Predsedatel Vsesoyuznogo Obedineniya „Tyaazhpromeksport”, Moskwa, 30 March 1961, [in:] AAN, KNiT, 787, sign. 40/245.

48. Informacja $i$ wnioski $w$ sprawie rozwoju technicznego pótprzewodników i podzespołów elektronicznych, Zespót Elektroniki i Telekomunikacji KNiT, [1966], [in:] AAN, KNiT, 787, sign. 10/52.

49. Sprawozdanie z pobytu delegacji PRL w ZSRR $w$ dniach 29 sierpnia - 6 września 1964, [in:] AAN, KNiT, 787, sign. 40/245.

50. Sprawozdanie z delegacji służbowej do ZSRR w sprawie Elektronicznej Techniki Obliczeniowej 3 października - 31 października 1965, Warszawa, December 1965, [in:] AAN, KNiT, 787, sign. 40/120.

51. RGAE, Ministerstvo Radiopromyshlennosti SSSR - Fond 23, Opis 1, Delo 1054, 1381 (60s).

52. RGAE, Gosudarstvennyy Komitet po Nauke i Tekhnike - Fond 9480, Opis 12, Delo 962.

53. RGAE, Gosudarstvennyy Komitet SSSR po vychislitelnoy tekhnike i informatike - Fond 680, Opis 1, Delo 71, 72, 75, 189.

54. Mirosław Sikora, Clandestine Acquisition of Microelectronics and Information Technology by the Scientific-Technical Intelligence of Polish People's Republic in 1970-1990, [in:] 2017 Forth International Conference "Computer Technology in Russia and in the Former Soviet Union” SoRuCom 2017, 3-5 October 2017 Zelenograd, Russia, ed. Irina Krayneva, Alexander Tomilin, IEEE 2017.

55. Frank Cain, Computers and the Cold War: United States Restrictions on the Export of Computers to the Soviet Union and Communist China, "Journal of Contemporary History", Vol. 40 (1), 2005.

56. Jonathan R. Zatlin, Out of the sight: Industrial Espionage, Ocular Authority and East German Communism, 1965-1989, "Contemporary European History”, Vol. 17 (1), 2008.

57. Gus W. Weiss, Duping the Soviets. The Farewell Dossier, „Studies in Intelligence”, Vol. 39, No. 5 (1996)

58. Michael Mastanduno, Economic Containment. CoCom and the Politics of East-West Trade, Ithaca (NY): Cornell University Press 1992.

59. Éric Merlen, Frédérick Ploquin, Carnets intimes de la DST. 30 ans au coeur du contreespionnage français, Fayard 2003.

60. Soviet Acquisition of Militarily Significant Western Technology: An Update, Office of the Undersecretary of Defense, Memorandum for Administration Defense Technical Information Center, September 1985.

61. Jan Bury, Polska Informatyka: Informatyka w służbach specjalnych PRL. Analiza kryminalistyczna, PTI, Warszawa 2017.

62. AIPN, sign. 01789/211 (years 1971-1983).

63. AIPN, sign. 02320/419, Vol. 1-2 (years 1984-1987).

64. Martin Schmitt, Internet im Kalten Krieg. Eine Vorgeschichte des globalen Koтmunikationsnetzes, transcript Verlag, Bielefeld 2016.

65. Andrzej Targowski, Historia, teraźniejszość, przyszłość informatyki, Wydawnictwo Politechniki Łódzkiej, Łódź 2013. 
66. AIPN, sign. 01789/211.

67. AIPN, sign. 0211/963 (jacket).

68. AIPN, sign. 001912/5.

69. Cpravka ob usilenii so storony Zapada nad eksportoi v SSSR i deyatelnosti spetssluzhb protivnika na etoi napravlenii $\mathrm{v}$ usloviyakh perestroyki sovetskoy ekonomiki, OCH011727/P/89, 23 November 1989, [in:] AIPN, sign. 0449/26, Vol. 25.

70. KRLD - Notatka Nr 9226/PRL, Warszawa, 6 April 1987, [in:] AIPN 02271/21, Vol. 7.

71. Mirosław Sikora, Intelligence-interchange in the area of Science and Technology between Poland and Soviet Union, 1986-1990, [in:] Technology in Times of Transition. 41 ICOHTEC Symposium 2014, ed. E. Helerea, M. Cionca, M. Ivănoiu, Transylvania University of Brasov 2014.

72. Robert Lindsey, Some Losers in Silicon Valley said to find wealth in spying, "Special to New York Times", 23 October 1983.

73. AIPN, sign. 02271/21, Vol. 3, 19, 21 (unilateral meetings, debriefings and data transfer), Vol. 10, 32 (Exchange Poland-Bulgaria), Vol. 14, 26, 36 (exchange Poland - Czechoslovakia), Vol. 11,12, 28 (exchange Poland-GDR), Vol. 13, 24 (exchange Poland-Hungary), Vol. 5-6, 16-18, 20-22, 27, 30-31, 37 (exchange Poland-USSR).

74. AIPN, sign. 01592/474, operation codename "Dekus".

75. AIPN, sign. 02110/51, Vol. 1-2, operation codename "Deram".

76. Raport dot. Założenie PRO krypt. „Archimedes” dla Naczelnika Wydziału VI Dep. I MSW, Warszawa, 16 December 1987, [in:] AIPN, sign. 02320/609.

77. Henrik Bischof, Das „Eureka” - Projekt Osteuropas. Zur Entwicklung der Schlüsseltechnologien in den RGW-Staaten, Studie der Abteilung Aussenpolitik- und DDR-Forschung im Forschungsinstitut der Friedrich-Ebert-Stiftung, Bonn 1986.

78. Grażyna Monkiewicz, Jan Monkiewicz, Jerzy Ruszkiewicz, Zagraniczna Polityka Naukowo-Techniczna Polski. Diagnoza, uwarunkowania, kierunki, Wydawnictwo PAN Zakład Narodowy im. Ossolińskich, 1989.

79. Wayne Sandholtz, High-Tech Europe. The politics of international cooperation, University of California Press Los Angeles, Berkley Oxford 1992.

80. Instrukcja operacyjna $\mathrm{Nr}$ 1/0/88 z dnia 1988.01.18 „DIS” Rzym, [in:] AIPN, sign. 02320/609.

81. Notatka informacyjna dot. udziału Austrii w pracach „Eureka” $i$ nowego programu badawczego FAMOS, „Dan”, Wiedeń, 18 February 1988, [in:] AIPN, sign. 02320/609.

82. KBP ZSRR - Notatka $n r$ 8923/PRL, Warszawa, 26 March 1986, [in:] AIPN, sign. 02271/21, Vol. 37.

83. Kristie Macrakis, Does Effective Espionage Lead to Success in Science and Technology? Lessons from the East German Ministry for State Security, „Intelligence and National Security", vol. 19, Spring 2004, s. 71. 